\title{
Effects of diets containing different concentrations of pollen and pollen substitutes on physiology, Nosema burden, and virus titers in the honey bee (Apis mellifera L.)
}

\author{
Emily Watkins de JonG ${ }^{1}$, Gloria DeGrandi-Hoffman ${ }^{1}$, Yanping $\mathrm{CHEN}^{2}$, \\ Henry GRAHAM ${ }^{1}$, Nick ZiOLKOWSKI ${ }^{1}$ \\ ${ }^{1}$ USDA-ARS Carl Hayden Bee Research Center, 2000 East Allen Road, Tucson, AZ 85719, USA \\ ${ }^{2}$ USDA-ARS Bee Research Laboratory, Beltsville, MD 20705, USA
}

Received 1 February 2019 - Accepted 2 October 2019

\begin{abstract}
Colonies of Apis mellifera provided with natural forage show decreased pathogen loads and increased overwintering success when compared with colonies provisioned with supplemental protein diets. Despite the potential benefits of a pollen-based diet, protein supplements are commonly used in colonies throughout the spring and increasingly through the fall and winter as the cost of pollen is greater than that of supplements and concerns exist over the potential for pollen to vector viruses to bee colonies. In this study, we compare virus and Nosema burden, consumption and digestion, hemolymph protein and hypopharyngeal gland size in bees fed on pure pollen diets, purely supplemental protein diets, and diets containing $90 \%$ supplement and $10 \%$ pollen to examine whether the inclusion of small amounts of pollen mitigates the negative impacts of consuming protein supplements seen in preceding studies. We found that the diets had similar concentrations of total soluble protein; however, bees consumed and digested significantly more of the pollen diet than either PS alone or mixed with pollen. In colonies, honeybees consuming pollen had lower deformed wing virus (DWV) and Nosema titers than bees fed protein supplements. The addition of $10 \%$ pollen to the supplement significantly increased digestion and hypopharyngeal gland size and decreased levels of Nosema infection over colonies fed supplement alone. These results indicate that the addition of small amounts of pollen into protein supplements may help to mitigate the differences observed between protein supplement and pollen fed bees.
\end{abstract}

honey bee nutrition / Nosema / deformed wing virus / hypopharyngeal gland / supplementary feeding

\section{INTRODUCTION}

The nutrients necessary for growth and development in Apis mellifera are encompassed in a diet of pollen and nectar. Nectar provides carbohydrates necessary for fueling flight, and pollen provides protein and other resources essential for rearing brood to adulthood (Brodschneider and Crailsheim 2010). Adequate protein consumption

Corresponding author: E. Watkins de Jong, ewatkinsdejong@email.arizona.edu Handling editor: Cedric Alaux is required for sustaining a variety of pathways crucial to colony health (DeGrandi-Hoffman et al. 2010; Di Pasquale et al. 2013). The amino acids derived from the protein component of a honeybees' diet are essential constituents of immune functions and hypopharyngeal growth among other vital physiological operations (Casteels et al. 1990; Cotter et al. 2011).

A variety of commercially available protein supplements are available to beekeepers when pollen resources are scarce or not available, usually occurring in early spring or during overwintering when floral resources are not abundant and weather may not permit foraging. 
Colonies intended for early year pollination of crops, such as almonds, are increasingly fed supplements to promote vigorous brood rearing before being transported to orchards. Although pollen and the protein supplements contain similar levels of soluble proteins (Human and Nicolson 2006; DeGrandi-Hoffman et al. 2016), protein supplements appear to be less digestible than pollen and bee bread and contain lower concentrations of many of the amino acids found in natural forage which decreases overwintering success and increases pathogen loads (DeGrandi-Hoffman et al. 2016).

Poor nutrition can lead to impacts on stress resistance in Apis mellifera which may result in increases in parasite and pathogen titers as well as increased sensitivity to pesticides (Huang 2012). Significant differences exist in colonies fed on supplements during pollen dearth; however, when even a small amount of pollen becomes available, the negative effects resulting from supplement feeding appear mitigated and the quality of colonies fed on pollen or protein supplement becomes comparable (DeGrandi-Hoffman et al. 2008). Whether or not the addition of some pollen directly into a supplement will have similar effects to what was observed in field studies is unknown. In this study, we examined whether the addition of pollen to a protein supplement would improve the nutritional condition and lower virus and pathogen burden significantly over those fed protein supplement alone at both the cage and colony level.

\section{MATERIALS AND METHODS}

The study was conducted at the Carl Hayden Bee Research Center, Tucson, AZ, USA. The effects of protein supplement with and without added pollen were compared in bees in both cage and colony level studies. Diet consumption, digestion, and hypopharyngeal gland acini size were compared among the diet treatments to evaluate the effects of the diet on traits associated with brood rearing and colony growth. The effect of nutrition on immune response was indirectly inferred by comparing Nosema and virus titers among the three diet treatments. All bees used in this study were of the subspecies Apis mellifera ligustica from colonies containing a commercially produced and mated European queen (C.F. Koehnen \& Sons, Inc., Glenn, CA). Cage studies were conducted prior to colony studies to assess differences in consumption, digestion, hemolymph protein concentration, Nosema burden, hypopharyngeal gland size, and virus titers on 7 and 11 day old bees.

\subsection{Diets}

The pollen used for both the cage and colony studies was collected in the Spring of 2015 as corbicular loads from hives outfitted with pollen traps located in apiaries in the Sonoran Desert surrounding Tucson, AZ, USA. Pollen was stored at $-20{ }^{\circ} \mathrm{C}$ until used in the study. Corbicular pellets were ground into a fine powder using a coffee grinder (Mr. Coffee model 1DS77, Sunbeam, Boca Raton, FL) before mixing into patties. Pollen patties for the cage and colony experiments were made using methods described in DeGrandiHoffman et al. (2008). The same ground corbicular pollen was added to a commercially available protein supplement patty (BeePro® patties, Mann Lake, Hackensack, MN, USA. \#FD$355)$ in a 1:9 pollen to protein supplement ratio (by weight).

\subsection{Cage setup}

Frames of sealed brood close to emergence were removed from colonies of European honey bees (A. $m$. ligustica), and placed in frame cages in a dark, humidity, and temperature-controlled environmental room to emerge overnight (32-34 ${ }^{\circ} \mathrm{C}, 30-40 \%$ relative humidity). Newly emerged bees were collected and divided into 12 cages each containing 100 bees. Four cages were assigned to each diet treatment - pollen $(\mathrm{P})$, protein supplement (PS), or a 1:9 Pollen + protein supplement mixture (P+PS), and returned to the environmental room for the remainder of the experiment. All cages were supplied continuously with a $50 \%$ sucrose solution and water $(\mathrm{w} / \mathrm{v})$ in separate $30-\mathrm{mL}$ vials inserted in the top of each cage. Mortality in cages was measured daily, and dead bees were removed each day. This process 
was repeated for three separate trials of cage studies (Figure 1).

\subsection{Diet consumption}

Diets were fed to cages in plastic tubes $(2.2 \mathrm{~cm}$ in diameter) inserted on the side of each cage. The diet and tube were weighed as a single unit prior to

\section{CAGE STUDY}

\section{FOUR CAGES PER TREATMENT ESTABLISHED FROM NEWLY EMERGED BEES}

\section{DAY 0}

- Baseline Nosema

10 newly emerged bees sampled and analyzed individually for Nosema

- Baseline Virus

10 newly emerged bees sampled for virus

\section{DAY 7}

- Hemolymph

Five 7-day-old bees sampled for individual analysis

- HPG

Five 7-day-old bees sampled for individual analysis

- Hindgut protein

Five 7-day-old bees sampled for individual analysis

\section{- Nosema}

Five 7-day-old bees sampled for individual analysis

\section{DAY 11}

- Final virus

Ten 11 day old sampled for individual analysis feeding to cages. All diets were changed and reweighed on days 4,7 , and 11 to estimate consumption.

\subsection{Colony setup}

To determine the effects of the protein diet treatments in colonies, 15 colonies were

\section{COLONY STUDY}

FIVE COLONIES PER TREATMENT IN ENCLOSED FLIGHT AREA

\section{DAY 0}

- Baseline Nosema

10 newly emerged bees sampled and analyzed individually for Nosema

- $\quad$ Baseline Virus

10 newly emerged bees sampled for virus

\section{DAY 21}

- Midgut protease

Twenty-four nurse bees (bees seen actively participating in nursing behavior) sampled for pooled midgut analysis

- Hemolymph

Five nursing bees sampled for individual analysis

- $\quad H P G$

Five nursing bees sampled for individual analysis

- Nosema

Ten nursing bees sampled for incividual analysis

Figure 1. Sampling layout for cage and colony experiments. 
established in individual bays of an enclosed flight area at the Carl Hayden Bee Research Center, Tucson, AZ, USA, (DeGrandi-Hoffman et al. 2015). Each colony contained adult bees, brood, a marked laying queen (C.F. Koehnen \& Sons, Inc., Glenn, CA), and no pollen stores. The enclosed flight area has a total of 16 bays with dimensions of $2.5 \mathrm{~m}$ wide, $3.6 \mathrm{~m}$ long, and with a height of 4.3 $\mathrm{m}$. Bees cannot fly between bays. Colonies were provided with half pound $(227 \mathrm{~g})$ patties for each treatment (pollen, protein supplement, or a 1:9 pollen + protein supplement mixture), a $30 \%$ sucrose solution (w/v), and a water feeder ad libitum continuously throughout the study. Patties were replaced as they were consumed (Figure 1).

\subsection{Midgut protease}

Because consumption of the diets was not measured directly in colonies, measurements of enzymes responsible for hydrolysis of proteins down to amino acids, proteases, were used as a relative estimate of consumption of each diet. There is an inverse relationship between protease concentration and amount of protein consumed, so lower midgut protease concentrations were interpreted as an increase in digestion in this study (Muller et al. 1995; Dadd 1956; Blakemore et al., 1995, DeGrandi-Hoffman et al. 2015). To assess differences in consumption at the colony level, total midgut protease levels were measured using methods described in Eckholm et al. (2015). Succinctly, nurse age bees (adult workers observed feeding larvae) were collected from the brood frame of colonies housed in the enclosed flight area after one full brood cycle (21 days) following the introduction of the diets. 24 excised midguts per colony were pooled in 2-mL reinforced microvials (BioSpec Products, Inc.) containing $1500 \mu \mathrm{L} 50 \mathrm{mM}$ borate buffer $(\mathrm{pH}$ 8.5; Thermo Scientific) along with two 2.3-mm diameter chrome-steel beads (BioSpec Products). The pooled midguts were then homogenized using a mini beadbeater (BioSpec Products) and centrifuged for $5 \mathrm{~min}$ at $10,000 \times \mathrm{g}$. Five microliters of supernatant was transferred to a clean $2-\mathrm{mL}$ centrifuge tube containing $995 \mu \mathrm{L}$ borate buffer. Samples were stored at $-20{ }^{\circ} \mathrm{C}$ until analysis using the QuantiCleave Protease Assay Kit
(Thermo Scientific), following the manufacturer's instructions. The kit employs succinylated casein, which is cleaved at peptide bonds in the presence of available proteases existing in the midgut. TPCK-treated trypsin is included as a protease standard to which sample protease concentrations were compared.

\subsection{Soluble protein in pollen, diets, and hindgut}

As a measure of digestion, soluble protein concentrations of the ileum and rectum of 7 day old bees were measured and compared with soluble protein concentrations of the respective diet treatment. Seven-day-old workers were chosen because they consume more pollen than older workers (Crailsheim et al. 1992). A 1- $\mu \mathrm{L}$ sample of the hindgut contents was added to $999 \mu \mathrm{L}$ of PBS and $1 \%$ EDTA-free HALT protease inhibitor. Samples were stored at $-80{ }^{\circ} \mathrm{C}$ until analyzed using bicinchoninic acid (BCA) protein assay (\#23225, Thermo Scientific). Digestion was estimated by 1- ([total soluble hindgut protein]/[total soluble protein in diet]) (DeGrandi-Hoffman et al. 2016).

\subsection{Hemolymph collection and soluble protein analysis}

Hemolymph soluble protein concentrations were compared among the treatments as a measure of protein uptake in an approach similar to previous studies (DeGrandi-Hoffman 2016). Hemolymph protein concentrations were measured from five bees per cage at 7 days old from 5 bees per colony after one full brood cycle in colonies using methods described in DeGrandi-Hoffman et al. (2010, 2013). Hemolymph from five workers was pooled, and a $1-\mu \mathrm{L}$ sample was added to $99 \mu \mathrm{L}$ of PBS containing $1 \%$ EDTAfree Halt Protease Inhibitor Cocktail (HPIC) (\#78437, Thermo Scientific, Rockford, IL). Samples were stored at $-80{ }^{\circ} \mathrm{C}$ until analyzed using bicinchoninic acid (BCA) protein assay (\#23225, Thermo Scientific). Absorbance was measured at $562 \mathrm{~nm}$ with a Synergy HT spectrophotometer (BioTek Instruments, Inc., Winooski, Vermont). Protein concentration was quantified using a 
standard curve generated from serial dilutions of bovine serum albumin.

\subsection{Hypopharyngeal glands}

Hypopharyngeal glands were dissected from 5 bees per cage on day 7 and from five nurse bees from colonies after one full brood cycle of consuming the diet treatments. Bees were flash frozen in liquid nitrogen, and maintained at $-80{ }^{\circ} \mathrm{C}$ until their HPG were measured using previously described techniques (DeGrandi-Hoffman et al. 2010, 2017). Briefly, HPG were removed from head capsules and placed into a PBS buffer (37 $\mathrm{mM} \mathrm{NaCl}, 2.7 \mathrm{mM} \mathrm{KCl}$, and $10 \mathrm{mM}$ PO4, $\mathrm{pH}$ 7.4). The HPG were examined microscopically at $\times 60$ magnification, and the area $\left(\mathrm{mm}^{2}\right)$ of five randomly selected acini per bee was measured using the Leica Applications Suite v.3.8.0 software. Only acini with clear borders were measured. Acini areas were averaged among individuals to obtain an estimate of HPG size for the cage.

\subsection{Nosema levels}

Abdomens were removed and placed individually in an eppendorf tube with $1 \mathrm{~mL}$ of ultra-pure water, and crushed with a pestle. A $10-\mu \mathrm{L}$ sample was pipetted onto a hemocytometer and covered with a glass slip. Nosema spores were counted at $\times 40$ magnification and converted to total spores per bee using methods described in Fries et al. (2013). Baseline Nosema values were taken from 10 newly emerged bees at the beginning of the cage experiment before dividing bees among the cages. Nosema spores were measured in 5 bees per cage on day 7 . In colonies, 10 nurse bees (bees seen actively feeding larvae on brood frames) were sampled from each colony at the beginning and after one complete brood cycle (21 days) after introducing the diet treatments.

\subsection{Virus titers}

Ten bees were taken from each colony at the beginning (baseline) and the end of both the cage and colony experiments for viral analysis. All samples were flash frozen in liquid nitrogen and stored at $-80{ }^{\circ} \mathrm{C}$ until analyzed using SYBR-
Green real-time quantitative RT-PCR (qRT-PCR) for detection and quantification of seven viruses including black queen cell virus (BQCV), deformed wing virus (DWV), Israeli acute paralysis virus (IAPV), Kashmir bee virus (KBV), and Sac brood virus (SBV) using methods described in Chen et al. (2005). The primer sets used for RTPCR amplification were those used previously in Chen et al. (2005) and DeGrandi-Hoffman et al. (2010). qRT-PCR was performed using Stratagene's Mx3005Real-Time PCR System operated by MxPro qPCR software. qRT-PCR was carried out in a 50-11 reaction volume containing $25 \mathrm{ul}$ of 2Brilliant SYBR Green qRT-PCR Master Mix (Stratagene, La Jolla, CA), 0.41M each of forward and reverse primers, and $200 \mathrm{ng}$ of template RNA. The thermal profile parameters consisted of one cycle at $50{ }^{\circ} \mathrm{C}$ for $30 \mathrm{~min}$, one cycle at $95^{\circ} \mathrm{C}$ for $3 \mathrm{~min}$ followed by 30 cycles of $95^{\circ} \mathrm{C}$ for $30 \mathrm{~s}, 55^{\circ} \mathrm{C}$ for $1 \mathrm{~min}$, and $72^{\circ} \mathrm{C}$ for $30 \mathrm{~s}$. Negative controls (no reverse transcriptase and no template) were included in each run of the reaction. The positive control was purposely not included in the reaction in order to avoid any potential contamination. After amplification, a melting curve analysis was performed to determine the specificity of the PCR products. The PCR products were incubated for $1 \mathrm{~min}$ at $95{ }^{\circ} \mathrm{C}$, ramping down to $55^{\circ} \mathrm{C}$ at a rate of $0.2{ }^{\circ} \mathrm{C} / \mathrm{s}$. The dissociation curve was constructed using 81 complete cycles of incubation where the temperature was increased by $0.5^{\circ} \mathrm{C} /$ cycle, beginning at $55^{\circ} \mathrm{C}$ and ending at $95^{\circ} \mathrm{C}$. The expression of the housekeeping gene, b-actin, in each sample also was measured for normalization of real time qRT-PCR results using a pair of primers published previously (Chen et al. 2005). The output of qRT-PCR assays of each virus was interpreted by using the comparative $\mathrm{Ct}$ method ( $\Delta \Delta \mathrm{Ct}$ method).

\subsection{Statistical analysis}

One-way analysis of variance (ANOVA) were used to compare consumption, digestion, hemolymph protein concentration, digestion, hypopharyngeal gland acini size, $\log _{10}(n+1)$ transformed Nosema levels, and fold increase from baseline measures of virus titers in colonies, two-way full factorial ANOVA with interactions 
were used to compare the same measures in cages to include trial effects. Kruskal-Wallis tests were also performed on all measures to account for non-normal distribution of data. All parametric ANOVA analyses were performed using JMP (SAS Institute Inc, JMP 13.2.1); Kruskal-Wallis tests were performed in R (R Foundation for Statistical Computing, R 3.5.0)

Virus levels were quantified using the comparative $\mathrm{Ct}$ method ( $\Delta \Delta \mathrm{Ct}$ method) based on the number of cycles needed to generate a fluorescent signal above a predefined threshold. The average $\mathrm{Ct}$ value $(\Delta \mathrm{Ct})$ of each virus was normalized using the $\mathrm{Ct}$ value for housekeeping gene $\beta$-actin $(\Delta \mathrm{Ct}=$ (Average $\left.\mathrm{Ct}_{\text {target } \mathrm{x}}\right)-\left(\right.$ Average $\left.\mathrm{Ct}_{\beta \text {-actin }}\right)$ ). The group with the lowest $\Delta \mathrm{Ct}$ was chosen as a calibrator. The $\Delta \mathrm{Ct}$ value of each group was subtracted from the $\Delta \mathrm{Ct}$ of the calibrator to generate $\Delta \Delta \mathrm{Ct}$. The virus concentration in each treatment group was calculated using the formula $2^{-(\Delta \Delta \mathrm{Ct})}$ and expressed as an $n$-fold difference relative to the calibrator (Chen et al. 2005; Livak and Schmittgen 2001). To compare initial virus levels to the final samples, baseline values were used as the calibrator to calculate fold increase over the baseline.

\section{RESULTS}

\subsection{Protein concentration of diets}

Total soluble protein concentration did not differ significantly among the three diets $\left(F_{2,6}=\right.$ $0.832, p=0.480 ; \chi_{2}^{2}=2.241, p=0.326$ ). Pollen contained an average protein concentration of $351.557 \mathrm{mg} / \mu \mathrm{L}$, PS had a protein concentration $310.231 \mathrm{mg} / \mu \mathrm{L}$ and P+PS contained $331.690 \mathrm{mg} /$ $\mu \mathrm{L}$ total soluble protein.

\subsection{Consumption}

The amount of diet consumed in the cage studies was effected by diet type, but there was no interaction between diet type and trial (diet type: $F_{2,33}=28.537, p<0.0001$; diet type*trial: $F_{2,33}$ $=2.485, p=0.099$ ). Significantly differences were found among the consumption of each diet type with pollen having the largest amount consumed and PS having the least $\left(\chi_{2}^{2}=22.511, p<\right.$ 0.0001) (Figure 2).
Both a one-way ANOVA and Kruskal-Wallis rank sum test revealed significant effects of diet on total midgut protease concentration for nurse bees in colonies $\left(F_{2,15}=6.826, p=0.0105 ; \chi_{2}{ }_{2}=\right.$ $7.634, p=0.022)$. Colonies consuming pollen had significantly lower protease concentrations (i.e., higher relative protein consumption) than those consuming PS. Protease concentrations of colonies consuming P+PS did not differ significantly from either the pollen or PS (Figure 3).

\subsection{Mortality}

Mortality of bees in cages was not effected by diet or the interaction between diet type and trial (diet type: $F_{2,33}=0.667, p=0.521$; diet type*trial: $\left.F_{2,33}=0.163, p=0.851\right)$. Cages in the PS treatment had an average of $34.750 \pm 14.868 \%$ mortality after 11 days, $\mathrm{P}+\mathrm{PS}$ cages had an average mortality of $26.250 \pm 16.286 \%$, and mortality in pollen cages averaged $19.750 \pm 9.303 \%$.

\subsection{Digestion}

Estimates of protein digestion among the three trials in the cage depended on diet type but were not affected by trial (diet type: $F_{2,33}=12.237, p<$ 0.0001 ; diet type*trial: $F_{2,33}=0.605, p=0.553$ ). Protein digestion differed significantly among the three diets $\left(\chi_{2}^{2}=15.479, p=0.0004\right)$. Bees in the pollen treatment digested an average of $51.396 \pm$ $1.998 \%$ of soluble protein in the diets; this is significantly higher than P+PS (45.529 \pm $1.379 \%)$ or PS $(39.823 \pm 1.355 \%)$ (Figure 4$)$.

\subsection{Hemolymph protein}

No significant differences in hemolymph protein concentrations were detected in cages $\left(F_{2,24}\right.$ $=1.590, p=0.220)$ or colonies $\left(F_{2,12}=0.964, p\right.$ $=0.409$ ) among bees fed the three diets. Mean hemolymph protein concentrations in cages were $213.307 \pm 25.629 \mathrm{mg} / \mu \mathrm{L}$ in pollen fed bees, $299.373 \pm 49.770 \mathrm{mg} / \mu \mathrm{L}$ in bees fed P+PS, and $242.093 \pm 22.022 \mathrm{mg} / \mu \mathrm{L}$ in PS fed bees. Hemolymph protein concentrations did not differ at the colony level $\left(\chi_{2}^{2}=1.680, p=0.432\right)$. Mean hemolymph protein concentrations in colonies were $275.383 \pm 21.016 \mathrm{mg} / \mu \mathrm{L}$ in pollen fed bees, 
Total Diet Consumption in Cages

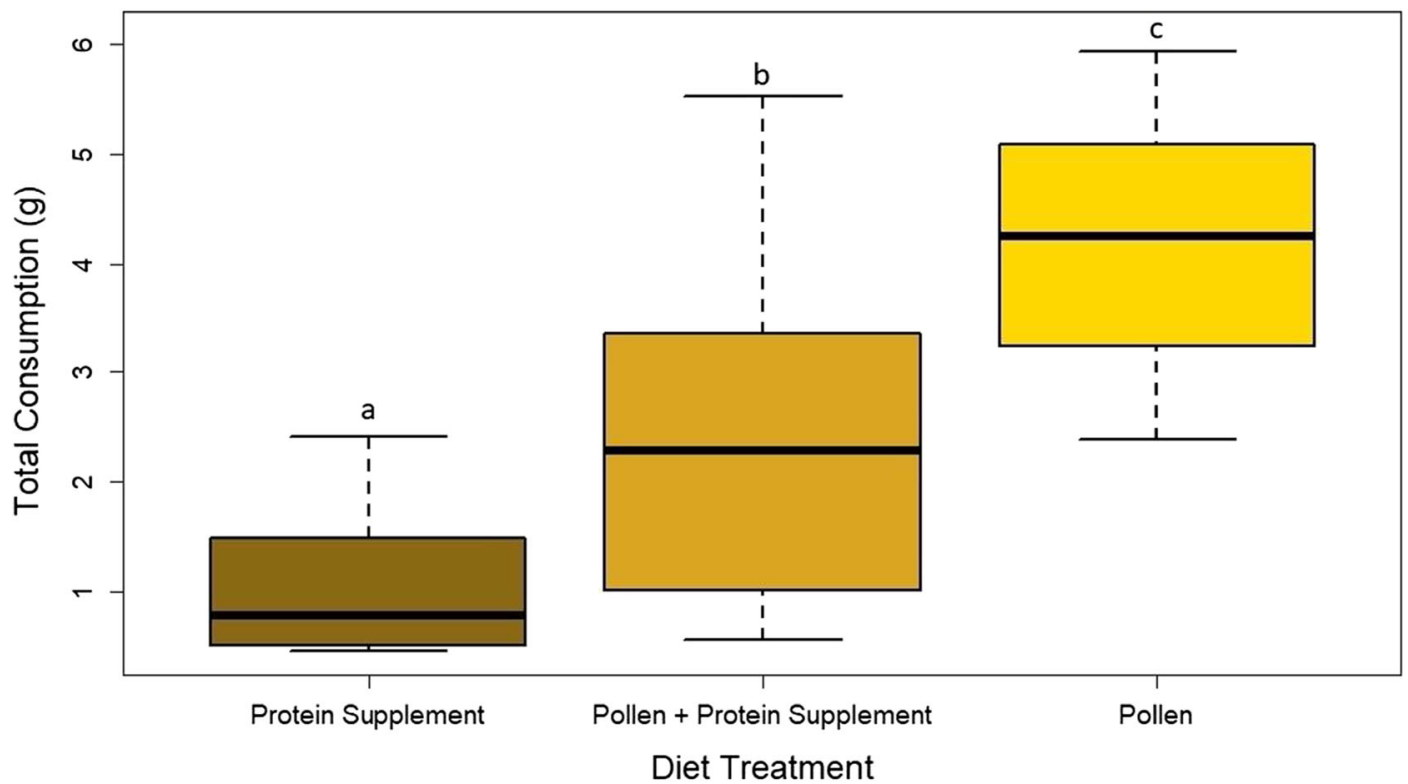

Figure 2. Total consumption of diets (PS, P+PS, Pollen) in cages. PS: $N=4, \mathrm{P}+\mathrm{PS}: N=4, \mathrm{P}: N=4$ pools of 5 bees. ANOVA: $p<.001$. Kruskal-Wallis: $\chi_{2}^{2}=22.511, p<0.0001$. Tukey's post hoc tests: pairwise comparisons resulted in significant differences among all treatments.

Total Protease Activity in Colonies

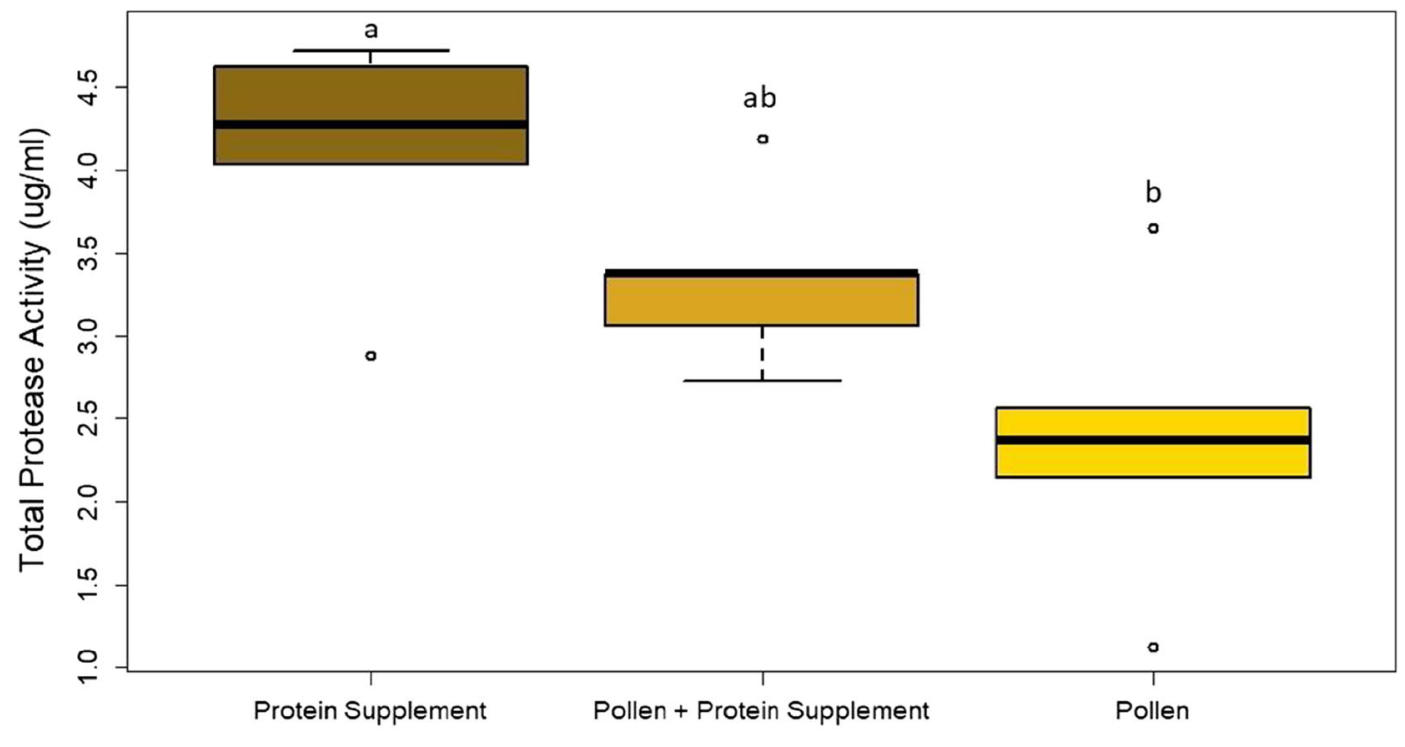

Diet Treatment

Figure 3. Total protease activity in colonies PS: $N=5$, P+PS: $N=5$, P: $N=5$ pools of 24 midguts. ANOVA: $p=$ .011. Kruskal-Wallis: $\chi_{2}^{2}=7.634, p=.022$. Tukey's post hoc tests: pairwise comparisons resulted in significant differences among pollen, and PS treatments. P+PS did not differ significantly from the pollen or P+PS treatment. 


\section{Percent Protein Digestion in Cages}

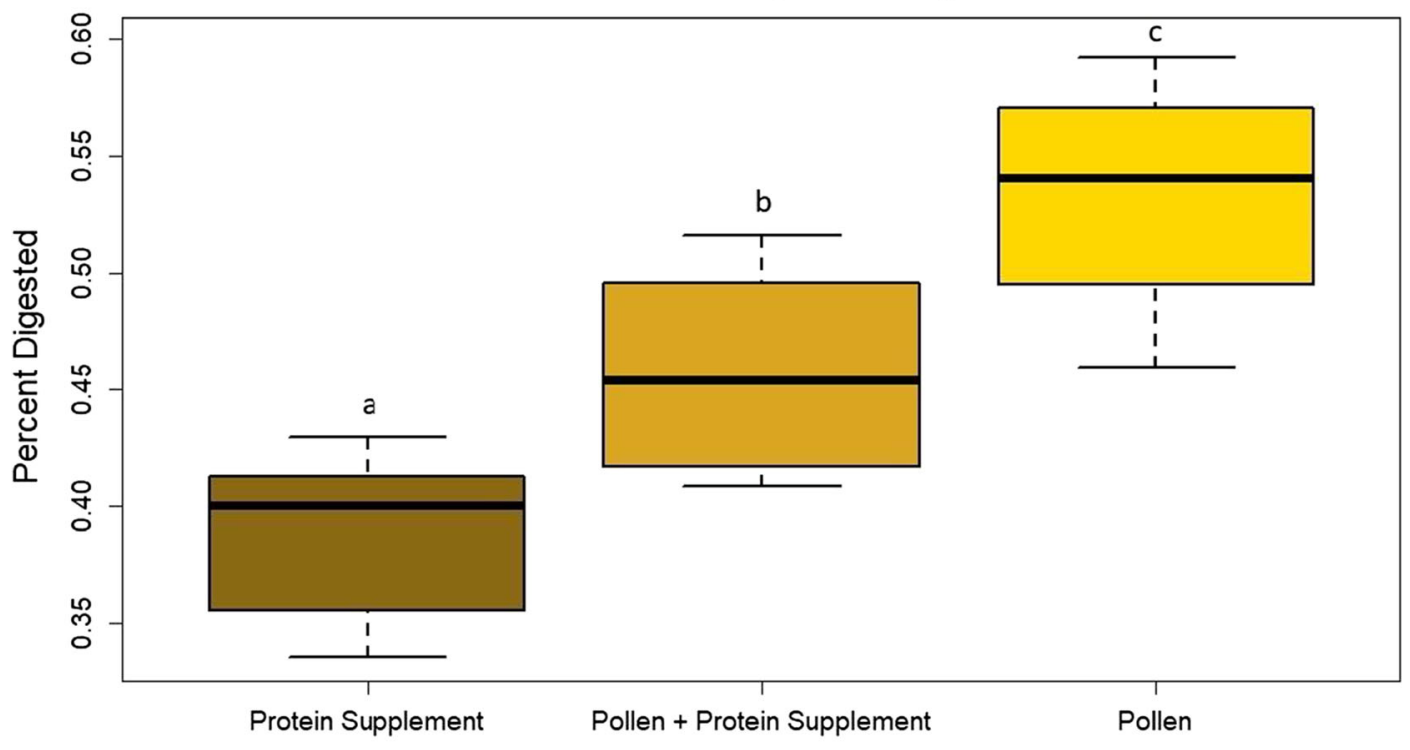

Diet Treatment

Figure 4. Percent protein digestion of diets in cages. PS: $N=4, \mathrm{P}+\mathrm{PS}: N=4, \mathrm{P}: N=4$ pools of 5 bees. ANOVA: $p<$ .0001 . Kruskal-Wallis: $\chi_{2}^{2}=15.479, p=.0004$. Tukey' post hoc tests: all pairwise comparisons resulted in significant differences.

$299.373 \pm 18.416 \mathrm{mg} / \mu \mathrm{L}$ in bees fed P+PS, and $242.093 \pm 15.454 \mathrm{mg} / \mu \mathrm{L}$ in PS fed bees.

\subsection{Hypopharyngeal gland size}

No significant differences were found among the three trials of the cage study (diet type: $F_{2,70}=$ $.1 .55, p=0.220$; diet type*rep: $F_{2,70}=.1 .735, p$ $\left.=.184 ; \chi_{2}^{2}=1.731, p=0.421\right)$. In the cage study, HPG had an average acinus size of $0.015 \pm 0.0007$ $\mathrm{mm}^{2}$ in the pollen treatment, PS cages had an average acinus size of $0.012 \pm 0.0007 \mathrm{~mm}^{2}$ and $\mathrm{P}+\mathrm{PS}$ acinus averaged $0.012 \pm 0.0005 \mathrm{~mm}^{2}$.

HPG size differed significantly among the treatments at the colony level with bees fed pollen $\left(0.015 \pm 0.0005 \mathrm{~mm}^{2}\right)$ and P+PS $(0.013 \pm 0.0008$ $\mathrm{mm}^{2}$ ) having larger acini areas than those fed PS $\left(0.010 \pm 0.0007 \mathrm{~mm}^{2}\right)\left(F_{2,12}=19.060, p=\right.$ $\left.0.0003 ; \chi_{2}^{2}=9.506, p=0.009\right)$. (Figure 5)

\subsection{Nosema}

Baseline Nosema infections were low with an average of $5000 \pm 5000.000$ spores/bee in the sample of newly emerged bees. Colonies had baseline averages of $4000 \pm 1095.445$ spores/bee in the pollen treatment, $2000 \pm$ 400.000 spores/bee in the P+PS treatment and $4000 \pm 1095.445$ spores/bee. Baseline Nosema counts did not differ significantly among treatments in colonies $\left(F_{2,12}=\right.$ $\left.0.250, p=0.783 ; \chi_{2}^{2}=0.560, p=0.756\right)$.

In the cage study, significant differences in Nosema spore counts were detected among the three diets $\left(F_{2,33}=6.800, p=0.003\right)$. The analysis was based on pooled data from the three trials $\left(F_{2,33}=0.370, p=0.694\right.$, $\left.\chi_{2}^{2}=11.369, p=0.003\right)$. Bees fed PS had significantly higher Nosema spore counts than those fed pollen. Nosema counts in bees fed P+PS (18333 \pm 4051.437 average spores/ bee) did not differ significantly from those fed pollen $(12500 \pm 4268.165$ average spores/bee) or PS (45000 \pm 8919.826 average spores/bee) (Figure 6a).

Significantly higher Nosema levels also were detected in bees from colonies fed PS $(960000 \pm 178241.409$ average spores/bee $)$ 


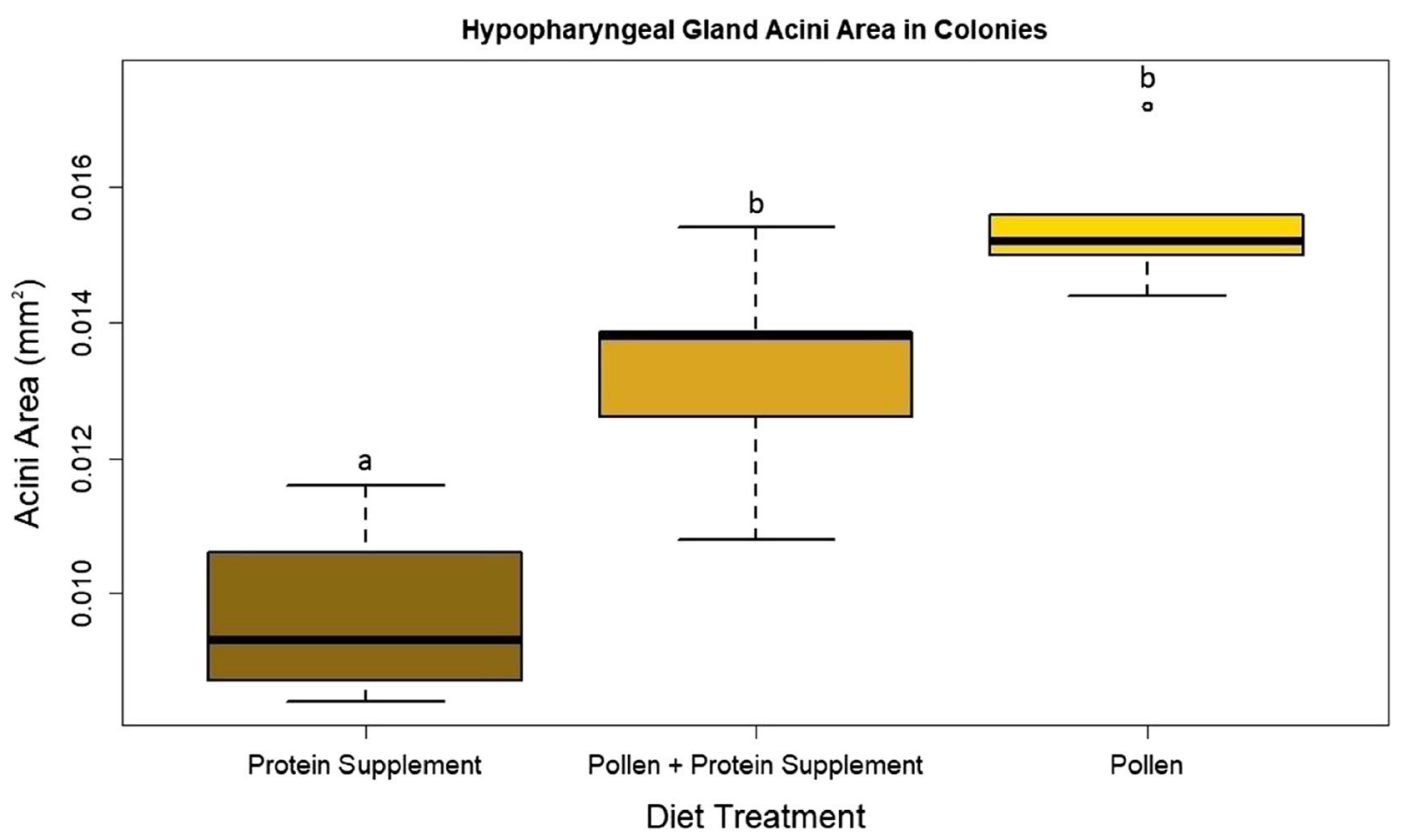

Figure 5. Hypopharyngeal gland acini area $\left(\mathrm{mm}^{2}\right)$ in colonies. PS: $N=25, \mathrm{P}+\mathrm{PS}: N=25, \mathrm{P}: N=25,5$ bees analyzed individually per colony. ANOVA: $p=.003$. Kruskal-Wallis: $\chi_{2}^{2}=9.506, p=.009$. Tukey's post hoc tests: pairwise comparisons resulted in significant differences among pollen, and PS treatments. P+PS did not differ significantly from the pollen treatment.

than those fed either pollen $(110000 \pm$ 38987.177 average spores/bee) or P+PS $(216000 \pm 46217.880$ average spores/bee $)$ $\left(F_{2,12}=18.620, p=0.0002 ; \chi_{2}^{2}=10.538\right.$, $p=0.005)$. Spore numbers in bees from colonies fed pollen or P+PS did not differ significantly (Figure 6b).

\subsection{Virus titers}

Of the seven viruses tested, only DWV was detected consistently in the final samples, and showed significant fold increases over the study period in colonies. No differences were detected in virus titers in the cage study $\left(F_{2,30}=1.073, p=0.356\right)$. Bees from colonies fed PS had significantly higher fold increases in DWV titers over baseline measures than pollen fed colonies $\left(F_{2,24}=, p=\right.$ $\left.0.021 ; \chi_{2}^{2}=6.413, p=.041\right)$. Fold increases in bees fed P+PS did not differ from pollen or PS (Figure 7).

\section{DISCUSSION}

We compared pathogen levels in honeybees fed pollen only to those fed PS alone and a 9:1 mixture with pollen. We also examined consumption and digestion rates of the three diets and the effects on HPG size. Soluble protein concentration of the diets did not differ significantly. We found that bees fed a protein supplement consumed and digested less diet than those fed pollen. Bees consuming protein supplements had smaller hypopharyngeal glands and had higher rates of Nosema infection and DWV titers. Bees that consumed a mixed diet of pollen and supplement consumed and digested more diet than those fed supplement alone in cages. In colonies, bees fed on P+PS had larger HPG acini size than those fed on PS and had significantly lower Nosema burden and lower DWV titers, although not significant. Because bees fed PS consumed less diet than those given pollen or $\mathrm{P}+\mathrm{PS}$, it is possible that differences in HPG size and parasite and 


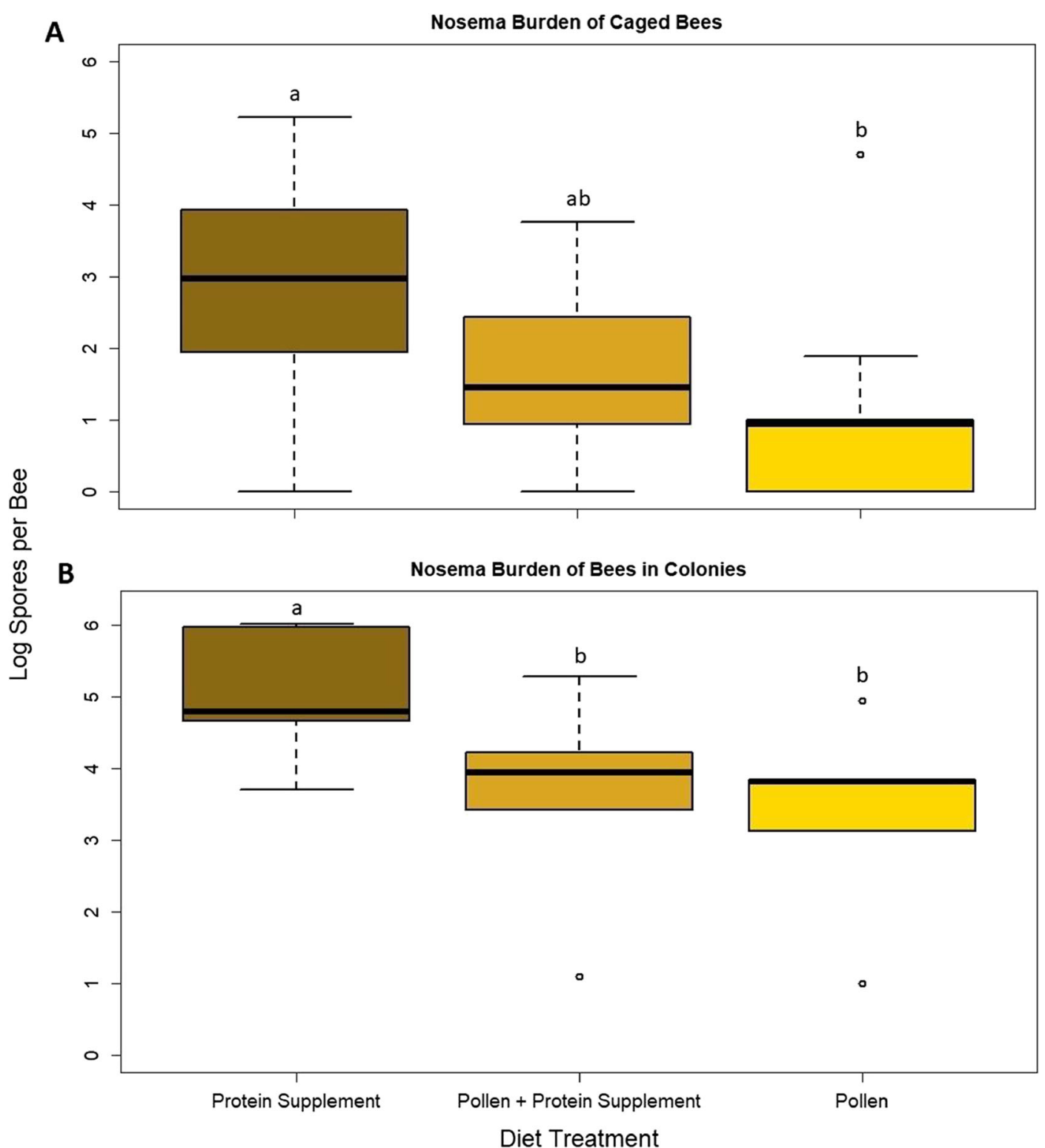

Figure 6: a Nosema burden of caged bees in $\log _{10}(n+1)$-transformed spores per bee. PS: $N=20, \mathrm{P}+\mathrm{PS}: N=20$, P: $N=20,5$ bees analyzed individually per cage. ANOVA: $p=.003$. Kruskal-Wallis: $\chi_{2}^{2}=11.369, p=.003$. Tukey's post hoc tests: pairwise comparisons resulted in significant differences among the pollen and PS treatments. b Nosema burden of bees in colonies, $\log (n+1)$-transformed spores per bee PS: $N=50, \mathrm{P}+\mathrm{PS}: N=50, \mathrm{P}: N=50$, 10 bees analyzed individually per colony. ANOVA: $p=.0002$. Kruskal-Wallis: $\chi^{2}{ }_{2}=10.538, p=.005$. Tukey's post hoc tests: pairwise comparisons resulted in significant differences among pollen, and PS treatments. P+PS did not differ significantly from the pollen treatment.

pathogen burden are due to differences in the ingested amount rather than diet quality. However if bees are not attracted to a diet and consumes less as a result, this may prompt a cycle of poor nutrition and nutritional stress which can contribute to an increase in 
Fold increase in Deformed Wing Virus Titers over Baseline in Colonies

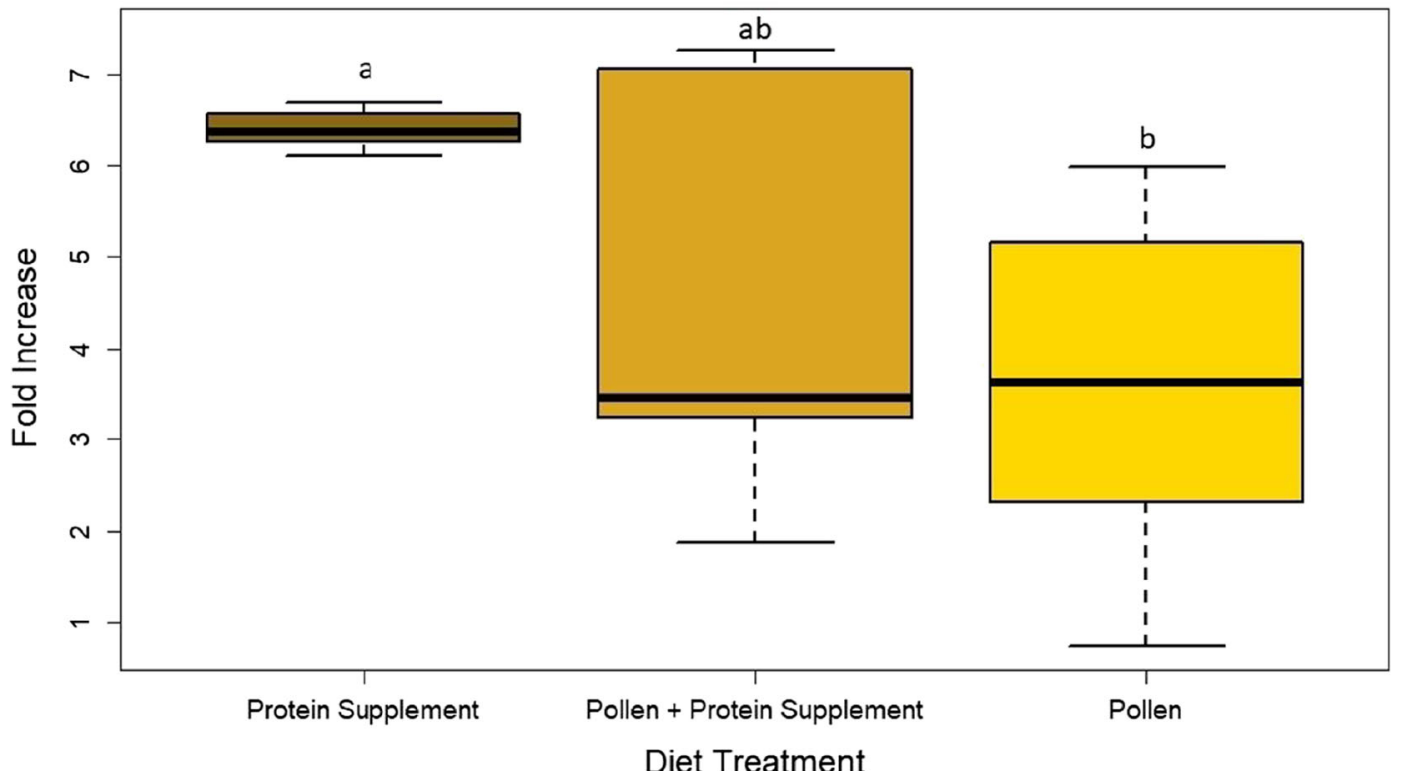

Figure 7. Deformed wing virus titers in fold increase over baseline titers in colonies PS: $N=50$, P+PS: $N=50$, P: $N$ $=50,10$ bees analyzed individually per colony. ANOVA: $p=.021$. Kruskal-Wallis: $\chi_{2}^{2}=\chi_{2}^{2}=6.413, p=.041$. Tukey's post hoc tests: pairwise comparisons resulted in significant differences between pollen and PS treatment. No significant differences were found between PS and P+PS.

susceptibility to parasites and disease as well as other negative impacts on physiology and health.

Though concentrations of total soluble proteins were similar in all three diets, there were lower digestion rates PS in both cages and colonies. Various studies have indicated that there is a postprandial decrease in available protease concentration in other insect systems (Muller et al. 1995; Dadd 1956; Blakemore et al. 1995) and DeGrandiHoffman et al. (2016) demonstrated an inverse relationship between pollen consumption and protease concentration in Apis mellifera, thus lower midgut protease concentrations were interpreted as an increase in consumption in this study. This may be due to ingredients in PS that include protein sources such as soy or barley flour and eggs, which are outside of the scope of the natural diet of honeybees. Bees fed PS alone also had the highest Nosema levels, and this may have contributed to lower digestion rates. Nosema replicates in midgut tissues and likely impairs digestion and nutrient absorption (Mayack and Naug 2009; Martín-
Hernández et al. 2011; Huang 2012; Holt et al. 2013) thereby intensifying nutritional stress.

Despite differences in protein consumption and digestion in cages and colonies, there were no observed differences in nurse hemolymph protein concentrations among the three diet treatments. Others have reported no effect in total soluble hemolymph protein during protein stress, but protein resources were allocated differently at the individual and colony level with stressed colonies producing less brood (Rueppell et al. 2008; Brodschneider and Crailsheim 2010; Willard et al. 2011). Nurses play a central role in the processing and allocation of protein within the colony (Crailsheim 1990). Hemolymph protein is in transit to be allocated to necessary physiological functions (Lensky and Rakover 1983). It may be that protein concentrations in the hemolymph are in homeostasis and other physiological traits, such as hypopharyngeal growth and immune function, shift in response to resource availability (Toth et al. 2005). This seemed to be the case in our study. 
Diet was a significant factor in HPG size in both cages and colonies. In the cage study, bees consuming pollen had larger HPG than those consuming PS or P+PS. In colonies, bees fed pollen or P+PS had similar HPG size, and both were significantly larger than colonies consuming PS. HPG in bees provided with PS may be smaller because less of the protein in PS was digested compared with the other diets. The bees fed PS also had higher Nosema levels. Poor pollen nutrition has been implicated in a reduction of worker bees' resistance to Nosema (Porrini et al. 2011; Huang, 2012; Jack et al. 2016; DeGrandi-Hoffman et al. 2015). Recent work has shown that HPG development is reduced in bees infected with Nosema perhaps due to damage of midgut tissue or the appropriation of nutrients from the bee by Nosema (DeGrandi-Hoffman et al. 2018). In addition to size differences, HPG of Nosema infected bees show distinct physiological differences from healthy glands including smaller mitochondria and the collapse of intracellular ductules indicating that the HPG of Nosema infected bees may be non-functional or have reduced functionality (Wang and Moeller 1969, 1971). Factors other than diet may have been responsible for directly influencing HPG size. Decreased midgut proteolytic activity, as was seen in bees fed on supplements, may have led to a reduction in HPG function (Sagili et al. 2005). Lipid contents of the diets were not measured in this study; however, lipids and protein to lipid ratios are important factors in the quality of protein sources to bees and lower protein to lipid ratios may positively influence HPG growth (Corby-Harris et al. 2018). In future studies, including analysis of lipid content in diets would provide valuable information on the nutritional quality of the diets and may provide more insight into the differences in HPG growth observed in this study.

In addition to high Nosema titers, colonies fed PS also possessed the highest DWV titers. Pollen consumption and digestion are important factors affecting the expression of genes related to immune and metabolic function (Alaux et al. 2010, 2011). Fleming et al. (2015) indicated in a recent study that bees fed commercial PS may have similar or greater Nosema burden than those fed on pollen. The association between nutrition and immunity has been well established in a variety of organisms (França et al. 2009; Cotter et al. 2011) where immune function is negatively impacted by caloric restriction. Because PS contains essential amino acids at lower concentrations than pollen (DeGrandiHoffman et al. 2016), the expression of important immune pathways may be limited by restricting the synthesis of peptides in immune pathways (Grimble 2001; Schmid-Hempel 2005) which could result in increased susceptibility to viral infection.

Changes in deformed wing virus titers were observed in the colony portion of the study, but not in cages. Newly emerged bees used in cages were inspected for Varroa mites and those with mites were exempt from the study. Although the packages used in the colony portion of the study were treated for mites when they were received in April of 2015, colonies were not screened for mite abundance prior to the start of the study. Varroa are known vectors of deformed wing virus (Bowen-Walker et al. 1999; Gisder et al. 2009). It is possible that the presence of Varroa in colonies could have contributed to DWV titers in the colony portion of the study.

The results of this study suggest that the addition of pollen in small quantities into a protein supplement diet has positive effects on honeybees by increasing HPG size and reducing pathogen titers. Beekeepers who rely on protein supplements to rapidly grow colonies in preparation for pollination services may be inadvertently doing long-term damage to colonies because of the nutritional deficiencies of protein supplements. Beekeepers are hesitant to add pollen due to concerns of exposing their bees to pathogens. However, we found the highest pathogen loads in bees fed protein supplements. The cost of pollen also deters beekeepers from adding it to protein supplements. However, the investment of a small addition of natural pollen in supplements has the potential to mitigate some of the negative effects of feeding supplement alone and possibly prevent colony losses from malnutrition and disease during times of natural pollen dearth.

\section{FUNDING INFORMATION}

Funding provided by USDA-ARS. All commercially available protein supplements were purchased with ARS funds.

Effets d'une alimentation contenant des concentrations différentes de pollen et de substituts de pollen sur la 
physiologie, l'infestation de Nosema et les titres de virus chez l'abeille domestique (Apis mellifera $\mathbf{L}$.).

nutrition des abeilles mellifères / Nosema / DWV / glande hypopharyngienne / alimentation complémentaire.

Die Effekte von Diäten mit unterschiedlichen Pollenkonzentrationen und Pollenersatzstoffen auf Physiologie, Nosemabefall und Virustiter bei der Honigbiene (Apis mellifera L.).

Honigbienen-Ernährung / Nosema / DWV / Hypopharynxdrüse / Pollenersatzfütterung.

\section{REFERENCES}

Alaux, C., Ducloz, F., Crauser, D., \& Le Conte, Y. (2010). Diet effects on honeybee immunocompetence. Biology Letters , 6 (4), 562-565. https://doi.org/10.1098 /rsbl.2009.0986

Alaux, C., Dantec, C., Parrinello, H., \& Le Conte, Y. (2011). Nutrigenomics in honey bees: digital gene expression analysis of pollen's nutritive effects on healthy and varroa-parasitized bees. BMC Genomics, 12: 496. https://doi.org/10.1186/1471-2164-12-496

Blakemore, D., Williams, S., \& Lehane, M. J. (1995). Protein stimulation of trypsin secretion from the opaque zone midgut cells of Stomoxys calcitrans. Comparative Biochemistry and Physiology - Part B: Biochemistry And, 110 (2), 301-307. https://doi. org/10.1016/0305-0491(94)00156-O

Bowen-Walker PL, Martin SJ, Gunn A (1999) The transmission of deformed wing virus between honeybees (Apis melliferaL.) by the ectoparasitic mite Varroa jacobsoni Oud. J Invertebr Pathol. doi: https://doi. org/10.1006/jipa.1998.4807

Brodschneider R, Crailsheim K (2010) Nutrition and health in honey bees. Apidologie. doi: https://doi.org/10.1051 /apido/2010012

Casteels P, Ampe C, Riviere L, et al (1990) Isolation and characterisation of abaecin, a major antibacterial response peptide in the honey bee Apis mellifera. Eur J Biochem, 187(2):381-6.

Chen, Y. P., Higgins, J. A., \& Feldlaufer, M. F. (2005). Quantitative real-time reverse transcription-PCR analysis of deformed wing virus infection in the honeybee (Apis mellifera L.). Applied and Environmental Microbiology, 71 (1), 436-441. https://doi.org/10.1128 /AEM.71.1.436-441.2005

Corby-Harris, V., Snyder, L., Meador, C., \& Ayotte, T. (2018). Honey bee (Apis mellifera) nurses do not consume pollens based on their nutritional quality.
PLoS ONE, 13 (1):e0191050. https://doi.org/10.1371 /journal.pone.0191050

Cotter SC, Simpson SJ, Raubenheimer D, Wilson K (2011) Macronutrient balance mediates trade-offs between immune function and life history traits. Funct Ecol. doi: https://doi.org/10.1111/j.1365-2435.2010.01766.x

Crailsheim K (1990) The protein balance of the honey bee worker. Apidologie. https://doi.org/10.1051 /apido:19900504

Crailsheim K, Schneider LHW, Hrassnigg N, et al (1992) Pollen consumption and utilization in worker honeybees (Apis mellifera carnica): dependence on individual age and function. J Insect Physiol. https://doi. org/10.1016/0022-1910(92)90117-V

Dadd, R. H. (1956). Proteolytic activity of the midgut in relation to feeding in the beetles Tenebrio molitor $\mathrm{L}$. and Dytiicut marginalii L. J. Exp. Biol. 33, 311-04

De Grandi-Hoffman, G., Chen, Y., \& Simonds, R. (2013). The effects of pesticides on queen rearing and virus titers in honey bees (Apis mellifera L.). Insects , 4 (1), 71-89. https://doi.org/10.3390/insects4010071

DeGrandi-Hoffman G, Wardell G, Ahumada-Segura F, et al (2008) Comparisons of pollen substitute diets for honey bees: consumption rates by colonies and effects on brood and adult populations. J Apic Res. doi: https://doi.org/10.1080/00218839.2008.11101473

DeGrandi-Hoffman G, Chen Y, Huang E, Huang MH (2010) The effect of diet on protein concentration, hypopharyngeal gland development and virus load in worker honey bees (Apis mellifera L.). J Insect Physiol. doi: https://doi.org/10.1016/j.jinsphys.2010.03.017

Degrandi-Hoffman, G., Chen, Y., Watkins Dejong, E., Chambers, M. L., \& Hidalgo, G. (2015). Effects of oral exposure to fungicides on honey bee nutrition and virus levels. Journal of Economic Entomology, 108 (6), 2518-2528. https://doi.org/10.1093 /jee/tov 251

DeGrandi-Hoffman, G., Chen, Y., Rivera, R., Carroll, M., Chambers, M., Hidalgo, G., \& de Jong, E. W. (2016). Honey bee colonies provided with natural forage have lower pathogen loads and higher overwinter survival than those fed protein supplements. Apidologie, 47 (2), 186-196. https://doi.org/10.1007/s13592-015-0386-6

DeGrandi-Hoffman G, Corby-Harris V, DeJong EW, et al (2017) Honey bee gut microbial communities are robust to the fungicide Pristine $\AA$ consumed in pollen. Apidologie. doi: https://doi.org/10.1007/s13592-0160478-y

DeGrandi-Hoffman, G., Gage, S. L., Corby-Harris, V., Carroll, M., Chambers, M., Graham, H., Calle, S.N., Meador, C.A., Snyder, L.A., Ziolkowski, N. (2018). Connecting the nutrient composition of seasonal pollens with changing nutritional needs of honey bee (Apis mellifera L.) colonies. Journal of Insect Physiology, 109, 114-124. https://doi.org/10.1016/j. jinsphys.2018.07.002

Di Pasquale G, Salignon M, Le Conte Y, et al (2013) Influence of pollen nutrition on honey bee health: do pollen quality and diversity matter? PLoS One. doi: https://doi.org/10.1371/journal.pone.0072016 
Eckholm, B. J., Huang, M. H., Anderson, K. E., Mott, B. M., \& DeGrandi-Hoffman, G. (2015). Honey bee (Apis mellifera) intracolonial genetic diversity influences worker nutritional status. Apidologie, 46(2), 150-163. https://doi.org/10.1007/s13592-014-0311-4

Fleming, J. C., Schmehl, D. R., \& Ellis, J. D. (2015). Characterizing the impact of commercial pollen substitute diets on the level of Nosema spp. in Honey Bees (Apis mellifera L.). PLoS ONE, 10 (7):e0132014. https://doi.org/10.1371/journal.pone.0132014

França T, Ishikawa L, Zorzella-Pezavento S, et al (2009) Impact of malnutrition on immunity and infection. $\mathrm{J}$ Venom Anim Toxins Incl Trop Dis. doi: https://doi. org/10.1590/S1678-91992009000300003

Fries, I., Chauzat, M.-P., Chen, Y.-P., Doublet, V., Genersch, E., Gisder, S., ... Williams, G. R. (2013). Standard methods for Nosema research. Journal of Apicultural Research, 52 (1), 1-28. https://doi. org/10.3896/ibra.1.52.1.14

Gisder S, Aumeier P, Genersch E (2009) Deformed wing virus: replication and viral load in mites (Varroa destructor). J Gen Virol. doi: https://doi.org/10.1099 /vir.0.005579-0

Grimble RF (2001) Nutritional modulation of immune function. Proc Nutr Soc. doi: https://doi.org/10.1079 /PNS2001102

Holt HL, Aronstein KA, Grozinger CM (2013) Chronic parasitization by Nosema microsporidia causes global expression changes in core nutritional, metabolic and behavioral pathways in honey bee workers (Apis mellifera). BMC Genomics. doi: https://doi. org/10.1186/1471-2164-14-799

Huang Z (2012) Pollen nutrition affects honey bee stress resistance. Terr Arthropod Rev. doi: https://doi. org/10.1163/187498312X639568

Human H, Nicolson SW (2006) Nutritional content of fresh, bee-collected and stored pollen of Aloe greatheadii var. davyana (Asphodelaceae). Phytochemistry. doi: https://doi.org/10.1016/j. phytochem.2006.05.023

Jack, C. J., Uppala, S. S., Lucas, H. M., \& Sagili, R. R. (2016). Effects of pollen dilution on infection of Nosema ceranae in honey bees. Journal of Insect Physiology, 87, 12-19. https://doi.org/10.1016/j. jinsphys.2016.01.004

Lensky Y, Rakover Y (1983) Separate protein body compartments of the worker honeybee (Apis mellifera L.). Comp Biochem Physiol 75:607-615

Livak, K. J., \& Schmittgen, T. D. (2001). Analysis of relative gene expression data using real-time quantitative PCR and the 2(-Delta Delta C(T)) method. Methods (San Diego, Calif.), 25 (4), 402-8. https://doi.org/10.1006/meth.2001.1262

Martín-Hernández R, Botías C, Barrios L, et al (2011) Comparison of the energetic stress associated with experimental Nosema ceranae and Nosema apis infection of honeybees (Apis mellifera). Parasitol. Res. 109(3):605-12

Mayack C, Naug D (2009) Energetic stress in the honeybee Apis mellifera from Nosema ceranae infection. $\mathrm{J}$ Invertebr Pathol. doi: https://doi.org/10.1016/j. jip.2008.12.001

Muller HM, Vizioli J, della Torre A, et al (1995) Constitutive and blood meal-induced trypsin genes in Anopheles gambiae. Exp Parasitol. doi: https://doi. org/10.1006/expr.1995.1128

Porrini, M.P., Sarlo, E.G., Medici, S.K., Garrido, P.M., Porrini, D.P., Damiani, N., Eguaras, M.J., 2011. Nosema ceranae development in Apis mellifera: influence of diet and infective inoculum. J. Apic. Res. 50, 35-41. https://doi.org/10.3896/IBRA.1.50.1.04

Rueppell O, Linford R, Gardner P, et al (2008) Aging and demographic plasticity in response to experimental age structures in honeybees (Apis mellifera L). Behav Ecol Sociobiol. doi: https://doi.org/10.1007/s00265-0080591-7

Sagili RR, Pankiw T, Zhu-Salzman K (2005) Effects of soybean trypsin inhibitor on hypopharyngeal gland protein content, total midgut protease activity and survival of the honey bee (Apis mellifera L.). J Insect Physiol. doi: https://doi.org/10.1016/j. jinsphys.2005.04.003

Schmid-Hempel P (2005) EVOLUTIONARY ECOLOGY OF INSECT IMMUNE DEFENSES. Annu Rev Entomol. doi: https://doi.org/10.1146/annurev. ento.50.071803.130420

Toth AL, Kantarovich S, Meisel AF, Robinson GE (2005) Nutritional status influences socially regulated foraging ontogeny in honey bees. J Exp Biol. doi: https://doi.org/10.1242/jeb.01956

Wang DI, Moeller FE (1969) Histological comparisons of the development of hypopharyngeal glands in healthy and Nosema -infected worker honey bees. J Invertebr Pathol. doi: https://doi.org/10.1016/0022-2011(69 )90098-6

Wang D-I, Moeller FE (1971) Ultrastructural changes in the hypopharyngeal glands of worker honey bees infected by Nosema apis. J Invertebr Pathol. doi: https://doi. org/10.1016/0022-2011(71)90002-4

Willard LE, Hayes AM, Wallrichs MA, Rueppell O (2011) Food manipulation in honeybees induces physiological responses at the individual and colony level. Apidologie. doi: https://doi.org/10.1007/s13592-0110006-z

Publisher's note Springer Nature remains neutral with regard to jurisdictional claims in published maps and institutional affiliations. 